\title{
Serum matrix metalloproteinase-9 in children exposed to arsenic from playground dust at elementary schools in Hermosillo, Sonora, Mexico.
}

Leticia García-Rico ${ }^{1,2}$, Diana Meza-Figueroa ${ }^{3}$, Paloma I Beamer ${ }^{4}$, Jefferey L Burgess ${ }^{4}$, Mary K O'Rourke $^{4}$, Clark R Lantz ${ }^{5}$, Melissa Furlong ${ }^{4}$, Marco Martinez-Cinco ${ }^{6}$, Iram Mondaca-Fernandez ${ }^{7}$, Jose J. Balderas-Cortes ${ }^{7}$, Maria M. Meza-Montenegro ${ }^{7^{*}}$.

${ }^{1}$ Centro de Investigación en Alimentación y Desarrollo, A.C., Carretera Gustavo Astiazarán 46, 83304, Hermosillo, Sonora, México.

${ }^{2}$ Instituto Tecnológico de Sonora. Programa de Doctorado en Ciencias Especialidad en Biotecnología, 5 de Febrero 818 Sur, 85000, Cd. Obregón, Sonora, México.

${ }^{3}$ Universidad de Sonora. Departamento de Geología, División de Ciencias Exactas y Naturales, Rosales y Encinas, 83000 Hermosillo, Sonora, México.

${ }^{4}$ University of Arizona, Mel \& Enid Zuckerman College of Public Health, Tucson, Arizona, USA.

${ }^{5}$ University of Arizona. Department of Cellular and Molecular Medicine, Tucson, Arizona, USA.

${ }^{6}$ Universidad Michoacana de San Nicolás de Hidalgo. Facultad de Ingeniería Química, Morelia, Michoacán, México.

${ }^{7}$ Instituto Tecnológico de Sonora. Departamento de Recursos Naturales, 5 de Febrero 818 Sur, 85000, Cd. Obregón, Sonora, México.

\section{Corresponding author:}

Maria M Meza-Montenegro.

mezamontenegro@email.arizona.edu

Tel: 52 (644) $4109000 \quad$ Ext. 2105

ORCID:0000-0002-1199-9310 


\begin{abstract}
Arsenic exposure in adults has been associated with increased serum matrix metalloproteinase-9 (MMP-9), a biomarker which is associated with chronic respiratory disease, lung inflammation, cardiovascular disease and cancer. The objective of this study was to evaluate the association between serum MMP-9 levels in children, and arsenic exposure to playground dust. This cross sectional study examined of 127 children from five elementary schools, in Hermosillo, Sonora, Mexico. Playground dust samples were collected for each school and urine and blood samples were obtained. Arsenic was analyzed in the dust using a portable X-ray fluorescence (XRF) analyzer and the daily arsenic dust ingestion dose (CDI) was estimated. Total urinary arsenic was determined by Inductively Coupled Plasma/Optical Emission Spectrometry (ICP/OES). Serum was analyzed for MMP-9 using ELISA. Linear regression and linear mixed effects regression were used to assess the relationships between serum MMP-9 and arsenic exposure (arsenic levels in playground dust, log CDI and log urinary arsenic). Arsenic concentration in dust was positively associated with serum MMP-9 levels in crude analyses and after adjustment $(\mathrm{P}<0.01)$, MMP-9 and CDI were positively associated only after adjustment $(P<0.01)$, and no association was found between MMP-9 and urinary arsenic. Arsenic ingestion from contaminated playground dust is an important route for pediatric toxicity, demonstrated through an association with increased serum MMP-9 levels.
\end{abstract}


Keywords: serum MMP-9, arsenic, playground dust, children, lung disease

\section{Introduction}

Arsenic is a metalloid that is widely dispersed in the environment and occurs naturally and from anthropogenic sources in water, food, soil, and air (Kurzius-Spencer et al. 2015; Cubadda et al. 2015). Epidemiological studies have indicated that chronic ingestion and/or inhalation of arsenic has been associated with skin, neurological, cardiovascular, and pulmonary diseases, and lung and bladder cancers (Heck et al. 2009; IARC 2012; Cubadda et al. 2015). Arsenic is considered to be a Group I human carcinogen by the International Agency for Research on Cancer (IARC 2012). Arsenic may be involved in oxidative stress, DNA repair, modification of gene expression, and alteration of growth factors that may lead to cancer (Olsen et al. 2008), however, the toxicity mechanism of these alterations is unclear.

Arsenic may deposit in or on soils, pavement, sidewalks, playgrounds, etc., and resuspend in the atmosphere, affecting the urban environment quality and human health (Charlesworth et al. 2011), primarily among children who are more susceptible than adults to the adverse effects of dust inhalation and/or ingestion routes (Elom et al. 2013; Gamiño-Gutiérrez et al. 2013).

Elementary school playgrounds are of particular interest since children spend much of their day in school. Arsenic is reported from school playgrounds and classrooms near 
highly traveled roads (Chen et al. 2014). While specific play activities vary among children, the principal source of arsenic is the physical disturbance of previously deposited arsenic in the playground soil (Iribarren et al. 2009; Elom et al. 2013).

Dust from soil re-suspension plays an important role in the early development of respiratory chronic diseases. In Mexico, chronic respiratory diseases, such as asthma and chronic obstructive pulmonary disease (COPD), are currently among the top 10 causes of death, just below cardiovascular disease and cancer (INEGI 2017). The gravity of chronic respiratory disease is increased by the presence of environmental contamination. In addition, children are more vulnerable to environmental pollution due to the greater gastrointestinal absorption rates of contaminants and ingestion through hand-to-mouth pathways (Meza-Figueroa et al. 2007; Charlesworth et al. 2011; Chen et al. 2014).

Biomarkers are a useful method for quantifying contaminant exposure and its possible toxic impact on health. Biomarkers can be used as internal indicators of environmental exposure (exposure biomarkers) and may reflect early adverse effects (effect biomarkers) (Bauvois 2012; McClintock et al. 2012; Beamer et al. 2016). Urinary arsenic is widely used as an exposure biomarker through recent consumption of drinking water (McClintock et al. 2012; Burgess et al. 2013; Arcega-Cabrera et al. 2018). Numerous studies in various populations have found a positive correlation between urinary arsenic and drinking water (Meza et al. 2004; Caceres et al. 2005; Roberge et al. 2012; Calderón et al. 2013; Olivas-Calderón et al. 2015) but only a few investigations have found 
association of urinary arsenic with soil, dust, or food (Gamiño-Gutiérrez et al. 2013; Beamer et al. 2016; Kurzius-Spencer et al. 2015; Loh et al. 2016).

Metalloproteinases (MMPs) are used as biomarkers of effect and are a family of zincdependent endopeptidases and mediators of the changes in the microenvironment during tumor progression (Kessenbrock et al. 2010; Bauvois 2012; Dagouassat et al. 2012). MMPs play an important role in various physiological processes such as the regulation of cancers and inflammatory processes because they are overexpressed in a variety of malignant tumors. Their expression and activity are associated with tumor aggressiveness and a poor prognosis (Kessenbrock et al. 2010; Nadarajah et al. 2011; Bauvois 2012). Serum matrix metalloproteinase-9 (MMP-9), also known as gelatinase, is one of the most studied MMPs in the lungs, and is a sensitive biomarker of lung inflammation in humans as they are continually secreted in the airways (Josyula, et al. 2006). MMP-9 has a strong correlation with lung disease involved in remodeling airways (Olsen et al. 2008; Bauvois 2012).

Increased MMP-9 levels in humans have been linked to arsenic intake and/or arsenic excreted in urine due to the consumption of drinking water (Lantz et al. 2009; Burgess et al. 2013; Calderon et al. 2013; Kurzius-Spencer et al. 2015). A few studies have reported positive associations between serum MMP-9 levels in adults exposed to arsenic from drinking water or aggregate arsenic intake, i.e. water plus food, (Burgess et al. 2013; Kurzius-Spencer et al. 2015) or MMP-9 in sputum from children exposed to arsenic in 
drinking water (Olivas-Calderon et al. 2015), but there are no reported studies which evaluate the association between serum MMP-9 levels in children exposed to arsenic from soil or dust. In previous studies we have reported a potential health risk in children by exposure to multiple metals from various dust sources in Hermosillo, Sonora, and the high inorganic arsenic concentration in urban dust was one of the main contributors to the high risk value for the children (García-Rico et al. 2016).

Early detection of potential negative health effects in vulnerable populations is important, and allows implementing interventions before a disease from arsenic exposure can be developed. Although there is some evidence that environmental arsenic exposure from drinking water and/or food increases serum MMP-9 levels in adults and increases sputum MMP-9 concentrations in children and adults, serum MMP-9 levels have not been evaluated in children exposed to arsenic by playground dust. This study evaluates the association between serum MMP-9 levels in children, and arsenic exposure from playground dust.

\section{Material and Methods}

\section{Study area}

This study examined the playground areas of five elementary schools from Hermosillo, Sonora, which is located in the Sonoran Desert of northwestern Mexico, which extends to 
the bordering states of Arizona and California, and represents one of the most important arid zones in the world (Fig. 1). The weather conditions are typical of desert environments, with high temperatures ranging from 35 to $49{ }^{\circ} \mathrm{C}$ during summer and low temperatures ranging from 5 to $8{ }^{\circ} \mathrm{C}$ during winter at sea level. The climate is dry most of the year and the region is characterized by arid to semi-arid conditions with low annual precipitation (75 to $300 \mathrm{~mm}$ ). Hermosillo, the largest city in Sonora, is affected by dust emissions caused by winds including those resulting from thunderstorm activity, suspension due to traffic activity particularly on unpaved roads, and industrial activities.

\section{Participant selection}

Participants $(\mathrm{n}=127)$ were children from five public elementary schools of Hermosillo, Sonora, Mexico (Fig.1). Eligible families lived in the area for at least 2 years. The study protocol was approved by the Institutional Review Board of the Instituto Tecnologico de Sonora (ITSON). Participants and their parents or tutors were visited in the schools and were familiarized with the protocol. All participants provided written consent. The parent of each participant answered a questionnaire recording demographic and health information, and potential arsenic exposure sources. The parents and children also reported on the amount of tobacco exposure in the home. Each participant provided urine and blood samples, height and weight were measured.

\section{Playground dust collection}


Settled dust samples $(\mathrm{n}=20)$ were collected from playground areas of each school ensuring a representative sampling within the elementary schools. At each sampling site, surface dust was collected from a two meters square area using a polyethylene brush, trays, and containers. The collected dust samples $(200 \mathrm{~g})$ were dried at $35^{\circ} \mathrm{C}$ and sieved (\#635 mesh). The fine-grained fraction (passing \#635 mesh equivalent to $-20 \mu \mathrm{m}$ ) is most likely to be re-suspended by wind and anthropogenic activities and represents a fraction of the potentially ingested and inhaled dust $(<20 \mu \mathrm{m}$, containing the respirable fraction $\left.\mathrm{PM}_{10}\right)$.

\section{Biological sampling}

\section{Urine collection}

First morning void urine samples $(\mathrm{n}=127)$ were obtained in $100 \mathrm{~mL}$ polypropylene bottles and kept on ice and transported to the laboratory, where they were stored at $-20^{\circ}$ $\mathrm{C}$ until the analysis was performed.

\section{Blood collection}

Blood samples $(\mathrm{n}=127)$ were collected by venipuncture using a syringe and a serum separator tube. Samples were allowed to clot at room temperature for $30 \mathrm{~min}$ before 
centrifugation for $15 \mathrm{~min}$ at $3200 \mathrm{x}$ g. Serum was removed and separated into $0.5 \mathrm{~mL}$ aliquots, and stored at $-80^{\circ} \mathrm{C}$ until analysis.

\section{Analytical methods}

\section{Arsenic concentrations in playground dust}

Soil arsenic concentrations in the fine-grained fractions $(<20 \mu \mathrm{m})$ were analyzed in duplicate using a portable X-ray fluorescence (XRF) analyzer (Niton XL3t analyzer, Thermo Scientific) following the method 6200 from the USEPA field portable X-ray fluorescence spectrometry for the determination of elemental concentrations in soil and sediment. The detection limit for arsenic was $7 \mathrm{mg} / \mathrm{kg}$. To validate the quality of the acquired data, a subset of the samples was analyzed at the ALS CHEMEX Laboratory in Toronto, Canada. Results were compared by the obtained data, showing high correlation between both methods $(\mathrm{r}=0.995, \mathrm{p}<0.05)$

\section{Arsenic ingestion dose (CDI) from dust}

The arsenic intake attributed to playground dust was calculated as follow:

$\mathrm{CDI}(\mathrm{mg} / \mathrm{kg}-$ day $)=[\mathrm{C} \times \operatorname{IngR} \times \mathrm{ED} \times \mathrm{EF}] /[\mathrm{BW} \times \mathrm{AT}]$

were $\mathrm{C}$ is the metal concentration $(\mathrm{mg} / \mathrm{kg})$ in playground dust, $\mathrm{IngR}$ is dust ingestion for 
children (200 mg/day), ED is the exposure duration (in years), EF is the exposure frequency (365 days/year), and the averaging time (AT) is the ED multiplied by the average time (365 days) (USEPA 2013). In this study, ED and BW (in $\mathrm{kg}$ ) were taken from the survey of each participant.

\section{Analysis of total arsenic in urine}

Urinary arsenic was measured using ICP/OES (Thermo Scientific) after nitric acid sample digestion step. Briefly, urine samples $(4 \mathrm{~mL})$ were placed in a microwave digestion lineal vessel and $4 \mathrm{~mL}$ of concentrated nitric acid $\left(\mathrm{HNO}_{3}\right)$ and $2 \mathrm{~mL}$ of hydrogen peroxide $\left(\mathrm{H}_{2} \mathrm{O}_{2}\right)$ were added and digested (CEM Corp., Matthews, NC) for $35 \mathrm{~min}$ at $200^{\circ} \mathrm{C}$. After the microwave digestion, the samples were adjusted to a final volume of $25 \mathrm{~mL}$ with HPLC-grade water. For quality control purposes, blanks, duplicate samples and a Standard Reference Material SRM 3669, Arsenic Species in Frozen Human Material Urine (NIST, Gaithersburg, MD) were analyzed during the procedure. For this latter, the arsenic recovery was between $82-106 \%$ and the coefficient of variation was below $8 \%$, values among the acceptable range for quality control purposes. The quantification limit (LOQ) for arsenic averaged $1.0 \mu \mathrm{g} / \mathrm{L}$.

\section{Serum MMP-9 analyses}

The analyses of MMP-9 in serum was performed by enzyme-linked-immunosorbent 
assay (ELISA) (Human MMP-9 ELISA assay kit, Eagle Biosciences, Inc., MN, USA). Standards, blanks, and samples were analyzed in duplicated used and automated microplate reader (Labsystems multiskan Ascent model 35, Vantaa, Finland). The detection limit was $0.156 \mathrm{ng} / \mathrm{mL}$.

\section{Statistical analysis}

Statistical analysis was performed using Stata 15.0 (StataCorp, College Station, TX) and R V3.3.4. The relationships between serum MMP-9 levels and arsenic concentration in playground dust, arsenic ingestion dose (CDI) and urinary arsenic were evaluated using Spearman correlation coefficients. Linear regression and linear mixed effects regression models were used to assess the relationships between serum MMP-9 and arsenic exposure (arsenic from playground dust, $\log \mathrm{CDI}$ and $\log$ urinary arsenic). Models were adjusted for for age, sex, Body Mass Index (BMI), residence time and current children passive smoking status. For urinary arsenic and CDI models, a random effect for school was additionally included in both crude and adjusted mixed effects models. For urinary arsenic, values below the Limit of Quantification were imputed at $\mathrm{LOQ} / 2$. A $P$-value $<0.05$ was considered statistically significant.

\section{Results and discussion}




\section{Summary of children's characteristics}

Participants ranged in age from 4 to 14 years old, with a mean age of 8.7 years (Table 1). $53 \%$ of the participants were girls and $47 \%$ were boys. The mean value of the Body Mass Index (BMI) was of $16.6 \mathrm{~kg} / \mathrm{m}^{2}$, and $33 \%$ of children were exposed to tobacco in their homes (Table 1).

\section{Arsenic in dust}

The mean arsenic content in the playground dust was $16.9 \mathrm{mg} / \mathrm{kg}$ with a range of 10.5 to $23.1 \mathrm{mg} / \mathrm{kg}$, (Table 2). The higher levels were found at schools located at the north end of the city (Fig. 2). These arsenic levels were lower compared to those reported in Mexican mining zones such as S. L. Potosi, Mexico, with a mean value of $51.8 \mathrm{mg} / \mathrm{kg}$ (range: 15.4 to $263 \mathrm{mg} / \mathrm{kg}$ ) (Pérez-Vázquez et al. 2016), but were in consistent with those conducted by $\mathrm{Hu}$ et al. (2011), Chen et al. (2014) and Kong et al. (2011a, b). They detected average levels of $14.9 \mathrm{mg} / \mathrm{kg}$ in $<1 \mathrm{~mm}$ urban dust. Arsenic mean concentration in playground dust samples collected from the elementary schools was lower compared with the established value of the Mexican Norm for soil (22 mg/kg) [Table 2] and from other countries' guidelines such as Australia (100 mg/kg), England (32 mg/kg), and Germany (50 mg/kg) (Chen et al. 2014). 
Arsenic levels decreased as follows: ES-03>ES-02>ES-06>ES-05>ES-28 (Fig. 2). The concentrations of arsenic in playground dusts from the schools presented a range of behaviors. ES-02, ES-03, ES-06, school areas showed similar arsenic concentrations; $18.7 \pm 1.9,23.1 \pm 1.9,18.3 \pm 2.4$ respectively $(\mathrm{p}>0.05)$, these schools are located within the area of wind dispersion from agricultural areas occurring in the southwest of the city (Fig. 1). Del Rio-Salas et al. (2012) previously reported suspension processes related to SW-NW directed dominant winds in the study area, where a NW-SE oriented belt of hills at the eastern side of the city acts as a physical barrier that influences the spatial distribution of dust. Figure 1 shows a wind rose diagram with average wind (2001 to 2016), frequency circles every $10 \%$, and mean speed indicated.

Meanwhile, school ES-05 which is located in the center of the city and to the east of ES-02, ES-03, ES-06 presented average levels of $14.1 \mathrm{mg} / \mathrm{kg}$, closer to the arsenic background level in Sonora soil $(10.5 \mathrm{mg} / \mathrm{kg})$. This behavior may indicate different sources for the arsenic. In previous research conducted in this study area by MezaFigueroa et al. (2016), levels of total suspended particles (TSP) were detected at high levels in the ES-03 school area. In addition, García-Rico et al. (2016) estimated chronic metals health risk assessment in children by exposure to road dust in the north of the city of Hermosillo (where ES-03 school is located), and arsenic was the metalloid which most contributed to the value of Hazard Risk Quotient.

\section{Arsenic Ingestion Dose (CDI) from playground dust}


The CDI estimation include variables such as arsenic concentration, dust ingestion rates, exposure duration, exposure frequency, and body weight. The mean arsenic CDI by playground dust was $9.8 \mathrm{E}-07 \mathrm{mg} / \mathrm{kg}$-day (range: $4.1 \mathrm{E}-07$ to $2.1 \mathrm{E}-06 \mathrm{mg} / \mathrm{kg}$-day) (Table 1), with the highest values for those children that attended school ES-03, located in the North of the city. The mean arsenic CDI decreased as follows: ES-03>ES-02>ES-06> ES-05>ES-28, detecting significant variations between ES-28 and the rest of the schools $(P<0.05)$. For the CDI estimation, dust ingestion rates and the exposure frequency variables have constant values, thus arsenic concentration, exposure duration, and body weight are decisive variables in the estimation of CDI. For the present investigation, the lowest CDI level of arsenic $(10.5 \mathrm{mg} / \mathrm{kg})$ was found in ES-28, due in part to the greater weight $(19-66 \mathrm{~kg})$ of the children there. For the rest of the schools the CDI ranged from 14.1 to $23.1 \mathrm{mg} / \mathrm{kg}$-day.

\section{Urinary arsenic concentrations}

Arsenic concentrations detected in the urine collected from the children are shown in Table 2. In the present study arsenic was detected in $85 \%$ of the urine samples. This indicates that a high percentage of these children have recently been exposed to this metalloid, from various sources. The urinary arsenic mean was $34.9 \mu \mathrm{g} / \mathrm{L}$ (range: 2.39 to $200.6 \mu \mathrm{g} / \mathrm{L})$. The highest level of urinary arsenic was found among children who attended the schools located in the north of the city, with a value of $57.4 \mu \mathrm{g} / \mathrm{L}$, where the arsenic levels in playground dust also showed the highest values $(23.1 \mathrm{mg} / \mathrm{kg})$, above the 
established value of the Mexican Legislation (Table 2).

The mean urinary arsenic concentration from children in this study was higher than those reported in previous studies in children from Hermosillo (range: 9 to $28 \mu \mathrm{g} / \mathrm{L}$ ) by Wyatt et al. (1998), indicating the arsenic exposure from various sources in this population may have increased through the years.

When arsenic concentrations in urine were subsampled by geographic location of elementary schools, the highest excreted mean arsenic levels corresponded to children who attended the ES-03 school and decreased as follows: ES-03>ES-06>ES-05>ES-28> ES-02. The ES-03 school is located at the Northwest of the city, near to high trafficdensity roads, and also with the highest levels of arsenic in the playground dust.

On the other hand, when the urine levels excreted from the children were compared with the recommended value from the World Health Organization of $50 \mu \mathrm{g} / \mathrm{L}$ (WHO 2001), $18 \%$ of urine samples exceeded this criterion, and the children who attended ES-03 school presented the highest percentage above this criteria (41.2\%), followed by ES-05 (16.7\%), ES-06 (12.5\%), and ES-28 (9.4\%), while 100\% of children who attended ES-02 school had arsenic levels below the WHO guideline.

The arsenic concentrations in urine from the study group (mean $34.9 \mu \mathrm{g} / \mathrm{L}$, range: 2.40 to $200.6 \mu \mathrm{g} / \mathrm{L}$ ), were higher than those reported by Arcega-Cabrera et al. (2018) who detected low urinary arsenic levels in children from the southeast of Mexico (mean 13.6 $\mu \mathrm{g} / \mathrm{L}$, range: 0.2 to $33.6 \mu \mathrm{g} / \mathrm{L}$ ), but our results were similar to reports of children from the north and central part of Mexico (range: 3.2 to $215.9 \mu \mathrm{g} / \mathrm{L}$ ), and Chilean students (range: 
4.4 to $209 \mu \mathrm{g} / \mathrm{L}$ ), and lower that those reported for Spanish children (range: 0.07 to 926.2 $\mu \mathrm{g} / \mathrm{L}$, mean $71.8 \mu \mathrm{g} / \mathrm{L})($ Caceres et al. 2005; Torres-Sánchez et al. 2016; Yusà et al. 2018).

\section{Serum MMP-9 levels}

The serum MMP-9 levels are shown in Table 2. Serum MMP-9 concentrations ranged from 12.1 to $1144.4 \mathrm{ng} / \mathrm{mL}$, with a mean value of $438 \mathrm{ng} / \mathrm{mL}$. The serum MMP-9 levels were detected with the highest values in children who attended schools to the North, where the arsenic concentrations in playground dust were the highest. MMP-9 levels showed the same spatial distribution as shown by the arsenic concentrations in playgrounds and the arsenic excreted in urine.

On the other hand, arsenic levels in playground dust and CDI by playground dust were strongly correlated with serum MMP-9 concentrations, with Pearson partial correlation values of $(\mathcal{I}=0.4318, P=0.0000)$ and $(\mathcal{I}=0.3396, P=0.0001)$ respectively, but serum MMP-9 levels and the excreted arsenic in urine were not statistically significant ( $\int=$ 0.0302, $P>0.05$ ) [Fig. 2]. Linear regression and linear mixed effects regression models were used to assess the relationships between serum MMP-9 levels and arsenic concentration in playground dust, log CDI, and log urinary arsenic predictor variables (Table 3). After adjusted by age, sex, BMI, residential time in area, passive smoking, and 
random effect for school, the serum levels of MMP-9 were positively associated with arsenic in playground dust $(P<0.01)$ and CDI by playground dust. However, urinary arsenic levels did not achieve statistical significance with serum MMP-9 levels $(P=0.25)$, as was reported in other studies for MMP-9 concentrations and urinary arsenic excreted in children and adults from arsenic exposure to drinking water and food (Burgess et al. 2013; Cubadda et al. 2015; Kurzius-Spencer et al. 2015).

So far in the literature, there are very few reports of MMP-9 associated with low levels of arsenic exposure by various environment media (drinking water and food) and most of them have been done in adults exposed to arsenic by drinking water (Table 4). For example; Josyula et al. (2006) reported a positive association between arsenic excreted in urine and an increased ratio of Matrix Metalloproteinase-9/Tissue Inhibitor of Metalloproteinase 1 (MMP-9/TIMP-1) in sputum samples in adults from Ajo and Tucson, Arizona, exposed to arsenic by drinking water. These results suggest a toxic mechanism at low level arsenic drinking water exposure in these study populations $(<20$ $\mu \mathrm{g} / \mathrm{L})$. Burgess et al. (2013) carried out a study in adults from Arizona and Sonora looking for association between environmental arsenic exposure and MMP-9, and found that arsenic concentrations in drinking water and arsenic intake by water were positively associated with serum MMP-9 levels. Similar results were obtained from the children in our study where the serum MMP-9 levels were positively associated with arsenic concentrations in playground dust, and with the CDI by playground dust. There is only one study conducted by Kurzius-Spencer et. al. (2015) which reports a positive 
contribution of aggregate inorganic arsenic intake (food plus drinking water) to the serum MMP-9 levels in adults from four communities in Arizona, exposed at low arsenic levels via drinking water. These results showed that different sources of arsenic (like food) also increase the levels of MMP-9. In Mexico, there is only one report which associates the sputum MMP-9 levels with urinary arsenic and arsenic in drinking water, in children from Coahuila, Mexico, exposed at low and moderate levels of arsenic by drinking water. The results showed that sputum MMP-9 levels and the ratio (MMP-9/TIMP-1) were positively correlated with the arsenic concentrations in drinking water (Olivas-Calderon et al. 2015).

There were some limitations to our study. Data on dietary sources of arsenic for the study population were not available. It would therefore be useful to state whether or not the subjects ate food from their own production. Information regarding dietary intake, income, and class difference, between the children who lived on the north or south side of the city has not been obtained, in order to compare for possible impact on arsenic exposure and urinary excretion. Also, no information was available on the household exposures of the subjects, which may have potentially contributed to the findings if their household dust exposures varied similarly to those seen comparing the geographic regions of the schools.

\section{Conclusions}

This is the first investigation reported in children which relates serum MMP-9 levels with 
arsenic in playground dust (Table 4), and our results are similar to those reported from studies carried out in children in adults which evaluated the association between serum and sputum MMP-9 levels and environmental arsenic exposure by drinking water and food.

In conclusion, our study shows that serum MMP-9 levels in children are affected by arsenic from playground dust other important media of exposure, and may increase the concentration of this biomarker as a consequence of the arsenic toxicity.

\section{Acknowledgements}

This work was supported by funds provided by national Council of Science and Technology (CONACYT), through the Grants: CB-167676, FONSALUDS0008-2014-1-233976 and INFR-2016-1-269884, ITSON/PROFAPI-2018-0072. The authors would like to thank Ana Lilia López Duarte and Juan Fco. Maldonado Escalante for their technical assistance. This publication was financed with PFCE resources 2018. Special thanks to Dr. Paul W. Kilpatrick for his support with the English edition and valuable comments.

\section{References}

Arcega-Cabrera, F., Fargher, L., Quesadas-Rojas, M., Moo-Puc, R., Oceguera-Vargas, I., 
Noreña-Barroso, E., Yáñez-Estrada, L., Alvarado, J., González, L., Pérez-Herrera, N., \& Pérez-Medina, S. (2018). Environmental Exposure of Children to Toxic Trace Elements (Hg, Cr, As) in an urban area of Yucatan, Mexico: Water, blood, and urine levels. Bulletin of Environmental Contamination and Toxicology, 100(5), $620-626$.

Bauvois, B. (2012). New facets of matrix metalloproteinases MMP-2 and MMP-9 as cell surface transducers: Outside-in signaling and relationship to tumor progression. Biochemica et Biophysica Acta, 1825, 29-36.

Beamer, P. I., Klimecki, W. T., Loh, M., Van Horne, YO, Sugeng, A. J., Lothrop, N., Billheimer, D., Guerra, S., Lantz, R. C., Canales, R. A., \& Martinez, F. D. (2016). Association of children's urinary $\mathrm{CC} 16$ levels with arsenic concentrations in multiple environmental media. International Journal of Environmental Research and Public Health, 13(5), 521.

Burgess, J. L., Kurzius-Spencer, M., O’Rourke, M. K., Littau, S. R., Roberge, J., MezaMontenegro, M. M., Gutiérrez-Millán, L. E., \& Harris, R. B. (2013). Environmental arsenic exposure and serum matrix metalloproteinase-9. Journal of Exposure Science \& Environmental Epidemiology, 23(2), 163-169.

Caceres, D. D., Pino, P., Montesinos, N., Atalah, E, Amigo H, \& Loomis D. (2005). Exposure to inorganic arsenic in drinking water and total urinary arsenic concentration in a Chilean population, Environmental Research, 98, 151-159.

Calderon, R. L., Hudgens, E. E., Carty, C., He, B., Le, X. C., Rogers, J., \& Thomas, D. J. (2013). Biological and behavioral factors modify biomarkers of arsenic exposure in a U.S. population. Environmental Research, 126, 134-144.

Charlesworth, S., De Miguel, E., \& Ordóñez, A. (2011). A review of the distribution of particulate trace elements in urban terrestrial environments and its application to considerations of risk. Environmental Geochemistry and Health, 33, 103-123.

Chen, H., Lu X., \& Chang, Y. (2014). Heavy metal contamination in dust from kindergartens and elementary schools in Xi'an, China. Environmental Earth Sciences, 71, 2701-2709.

Cubadda, F., D’Amato, M., Mancini, F. R., Aureli, F., Raggi, A., Busani, L., \& 
Mantovani A. (2015). Assessing human exposure to inorganic arsenic in higharsenic areas of Latium: a biomonitoring study integrated with indicators of dietary intake. Annali di igiene, 27, 39-51.

Dagouassat, M., Lanone, S., \& Boczkowski, J. (2012). Interaction of matrix metalloproteinases with pulmonary pollutants. European Respiratory Journal, 39, 1021-1032.

Del Rio-Salas, R., Ruiz, J., De la O-Villanueva, M., Valencia-Moreno, M., MorenoRodríguez, V., Gómez-Alvarez, A., Grijalva, T., Mendivil, H., Paz-Moreno, F., \& Meza-Figueroa, D. (2012). Tracing geogenic and anthropogenic sources in urban dusts: Insights from lead isotopes. Atmospheric Environment, 60, 202-210.

Elom, N. I., Entwistle, J. A., \& Dean, J. R. (2013). How safe is the playground?. An environmental health risk assessment of $\mathrm{As}$ and $\mathrm{Pb}$ levels in school playing fields in NE England. Environmental Chemistry Letters, 11, 343-351.

Gamiño-Gutiérrez, S. P., González-Pérez, C. I., Gonsebatt, M. E., \& Monroy-Fernández, M. G. (2013). Arsenic and lead contamination in urban soils of Villa de la Paz (Mexico) affected by historical mine wastes and its effect on children's health studies by micronucleated exfoliated cells assay. Environmental Geochemistry and Health, 35, 37-51.

García-Rico, L., Meza-Figueroa, D., Gandolfi, A. J., Del Río-Salas, R., Romero, F. M., \& Meza-Montenegro, M. M. (2016). Dust metal sources in an urbanized arid zone: Implications for health risk assessments. Archives of Environmental Contamination and Toxicology, 70, 522-533.

Heck, J. E., Andrew, A. S., Onega, T., Rigas, J.R., Jackson, B. P., Karagas, M. R., \& Duell, E. J. (2009). Lung cancer in a U.S. population with low to moderate arsenic exposure. Environmental Health Perspectives, 117, 1718-1723.

Hu, X., Zhang, Y., Luo, J., Wang, T., Lian, H., \& Ding, Z. (2011). Biaccessibility and health risk of arsenic, mercury and other metals in urban street dusts from a megacity, Nanjing, China. Environmental Pollution, 159, 1215-1221.

IARC. (2012). A review of human carcinogens: Arsenic, metals, fibres, and dusts. Lyon. World Health Organization Press. 
https://www.ncbi.nlm.nih.gov/books/NBK304375/pdf/Bookshelf_NBK304375.pdf.

INEGI. (2017). Estadísticas a propósito del día de muertos (2 de noviembre). México. http://www.inegi.org.mx/saladeprensa/aproposito/2017/muertos2017Nal.pdf.

Iribarren, I., Chacón, E., \& De Miguel, E. (2009). A bayesian approach to probabilistic risk assessment in municipal playgrounds. Archives of Environmental Contamination and Toxicology, 56, 165-172.

Josyula, A. B., Poplin, G. S., Kurzius-Spencer, M., McClellen, H. E., Kopplin, M. J., Sturup, S., Lantz, R. C., \& Burgess, J. L. (2006). Environmental arsenic exposure and sputum metalloproteinase concentrations. Environmental Research, 102, 283-290.

Kessenbrock, K., Plaks, V., \& Werb, Z. (2010). Matrix Metalloproteinases: Regulators of the tumor microenvironment. Cell, 141, 52-67.

Kong, S., Lu, B., Ji, Y., Zhao, X., Chen, L., Li, Z., Han, B., \& Bai, Z. (2011a). Levels, risk assessment and sources of $\mathrm{PM}_{10}$ fraction heavy metals in four types dust from a coal-based city. Microchemical Journal, 98, 280-290.

Kong, S., Lu, B., Bai, Z., Zhao, X., Chen, L., Han, B., Li, Z., Ji, Y., Xu. Y., Liu, Y., \& Jiang. H. (2011b). Potential threat of heavy metals in re-suspended dusts on building surfaces in oilfield city. Atmospheric Environment, 45, 4192-4204.

Kurzius-Spencer, M., Harris, R. B., Hartz, V., Roberge, J., Hsu, C. H., O’Rourke, M. K., \& Burgess, J. L. (2015). Relation of dietary inorganic arsenic to serum matrix metalloproteinase-9 (MMP-9) at different threshold concentrations of tap water arsenic. Journal of Exposure Science \& Environmental Epidemiology, 26(5), 445-451.

Lantz, R. C., Chau, B., Sarihan, P., Witten, M. L., Pivniouk, V. I., \& Chen, G. J. (2009). In utero and postnatal exposure to arsenic alters pulmonary structure and function. Toxicology and Applied Pharmacology, 235, 105-113.

Loh, M. M., Sugeng, A., Lothrop, N., Klimecki, W., Cox, M., Wilkinson, S. T., Lu, Z., \& Beamer, P. (2016). Multimedia exposures to arsenic and lead for children near an inactive mine tailings and smelter site. Environmental Research, 146, 331-339.

McClintock, T. R., Chen, Y., Bundschuh, J., Oliver, J. T., Navoni, J., Olmos, V., Lepori, 
E. V., Ahsan, H., \& Parvez, F. (2012). Arsenic exposure in Latin America: Biomarkers, risk assessments and related health effects. Science of the Total Environment, 429, 76-91.

Meza-Figueroa, D., De la O-Villanueva, M., \& De la Parra, M. L. (2007). Heavy metal distribution in dust from elementary schools in Hermosillo, Sonora, México. Atmospheric Environment, 41, 276-288.

Meza-Figueroa, D., González-Grijalva, B., Del Río-Salas, R., Coimbra, R., OchoaLandin, L., \& Moreno-Rodríguez, V. (2016). Traffic signatures in suspended dust at pedestrian levels in semiarid zones: Implications for human exposure. Atmospheric Environment, 138, 4-14.

Meza, M. M., Kopplin, M. J., Burgess, J. L., \& Gandolfi, A. J. (2004). Arsenic drinking water exposure and urinary excretion among adults in the Yaqui Valley, Sonora México. Environmental Research, 96, 119-126.

Nadarajah, V. D., van Putten, M., Chaouch, A., Garrood, P., Straub, V., Lochmüller, H., Ginjaar, H. B., Aartsma-Rus, A. M., van Ommena, G. J. B., den Dunnen, J. T., \& 't Hoen, P. A. C. (2011). Serum matrix metalloproteinase-9 (MMP-9) as a biomarker for monitoring disease progression in Duchenne muscular dystrophy (DMD). Neuromuscular Disorders, 21, 569-578.

NOM-147-SEMARNAT/SSA1-2004. NORMA Oficial Mexicana, Que establece criterios para determinar las concentraciones de remediación de suelos contaminados por arsénico, bario, berilio, cadmio, cromo hexavalente, mercurio, níquel, plata, plomo, selenio, talio y/o vanadio. Diario Oficial de la Federación 2007.

Olivas-Calderón, E., Recio-Vega, R., Gandolfi, A. J., Lantz, R. C., González-Cortes, T., Gonzalez-De Alba, C., Froines, J. R., \& Espinosa-Fematt, J. A. (2015). Lung inflammation biomarkers and lung function in children chronically exposed to arsenic. Toxicology and Applied Pharmacology, 287(2), 161-167.

Olsen, C. E., Liguori, A. E., Zong, Y., Lantz, R. C., Burgess, J. L., \& Boitano, S. (2008). Arsenic upregulates MMP-9 and inhibits wound repair in human airway epithelial cells. American Journal of Physiology-Lung Cellular and Molecular Physiology, 
295, L293-L302.

Pérez-Vázquez, J., Flores-Ramírez, R., Ochoa-Martínez, A. C., Carrizales-Yáñez, L., Ilizaliturri-Hernández, C. A., Moctezuma-González, J., Pruneda-Álvarez, L. G., Ruiz-Vera, T., Orta-García, S. T., González-Palomo, A. K., \& Pérez-Maldonado, I. N. (2016). Human health risks associated with heavy metals in soil in different areas of San Luis Potosí, México. Human and Ecological Risk Assessment, 22, 323-336.

Roberge, J., O’Rourke, M. K., Meza-Montenegro, M. M., Gutiérrez-Millán, L. E., Burgess, J. L., \& Harris, R. B. (2012). Binational Arsenic Exposure Survey: Methodology and Estimated Arsenic Intake from Drinking Water and Urinary Arsenic Concentrations. International Journal of Environmental Research Public Health, 9, 1051-1067.

Torres-Sánchez, L., López-Carrillo, L., Rosado, J. L., Rodriguez, V. M., Vera-Aguilar, E., Kordas, K., García-Vargas, G. G., \& Cebrian, M. E. (2016). Sex differences in the reduction of arsenic methylation capacity as a function of urinary total and inorganic arsenic in Mexican children. Environmental Research, 151, 38-43.

USEPA. (2013). Regional screening levels (RSL) for chemical contaminants at superfund sites. USEPA, Washington, DC

WHO. (2001). Arsenic and Arsenic Compounds, 2nd edn. Environmental Health Criteria 224. Geneva 2001. http://www.inchem.org/documents/ehc/ehc/ehc224.htm.

Yusà, V., Pérez, R., Sánchez, A., Pardo, O., \& Roca, M. (2018). Exposure and risk assessment to arsenic species in Spanish children using biomonitoring. Science of the Total Environment, 628-629, 302-309.

Wyatt, C. J., Quiroga, V. L., Acosta, R. T. O., \& Méndez, R. O. (1998). Excretion of arsenic (As) in urine of children, 7-11 years, exposed to elevated levels of As in the city water supply in Hermosillo, Sonora, México. Environmental Research, 78, $19-24$. 
Table1. Summary characteristics from the children

\begin{tabular}{|c|c|c|c|c|c|}
\hline Characteristic & Total & ES-02 & ES-03 & ES-05 & $\mathbf{E}^{6}$ \\
\hline $\mathrm{n}$ & 127 & 17 & 17 & 24 & \\
\hline Male & $60(47 \%)$ & 7 & 4 & 15 & \\
\hline Female & $67(53 \%)$ & 10 & 13 & 9 & \\
\hline $\begin{array}{l}\text { Mean age } \\
\text { Range (vears) }\end{array}$ & $\begin{array}{c}8.7 \\
4-14\end{array}$ & $\begin{array}{c}8.4 \\
6-11\end{array}$ & $\begin{array}{c}8.8 \\
6-11\end{array}$ & $\begin{array}{c}8.7 \\
4-13\end{array}$ & \\
\hline $\begin{array}{l}\text { Mean BMI } \\
\text { Range }\end{array}$ & $\begin{array}{c}16.6 \\
10-22.8\end{array}$ & $\begin{array}{c}16.4 \\
16-16.1\end{array}$ & $\begin{array}{c}16.6 \\
14.6-23.1\end{array}$ & $\begin{array}{c}15.8 \\
14.1-22.8\end{array}$ & $\begin{array}{c}1 \\
10\end{array}$ \\
\hline $\begin{array}{l}\text { Mean water intake } \\
\text { Range (L/day) }\end{array}$ & $\begin{array}{c}1.5 \\
0.25-3.5\end{array}$ & $\begin{array}{c}1.9 \\
0.5-3.5 \\
\end{array}$ & $\begin{array}{c}1.5 \\
0.6-2.5 \\
\end{array}$ & $\begin{array}{c}1.5 \\
0.5-3.5\end{array}$ & 0. \\
\hline $\begin{array}{l}\text { Mean CDI dust } \\
\text { Range (mg/kg-day) }\end{array}$ & $\begin{array}{c}9.8 \mathrm{E}-07 \\
\text { 4.1E-07-2.1E-06 }\end{array}$ & $\begin{array}{c}1.3 \mathrm{E}-06 \\
9.3 \mathrm{E}-07-1.7 \mathrm{E}-06\end{array}$ & $\begin{array}{c}1.5 \mathrm{E}-06 \\
8.5 \mathrm{E}-07-2.1 \mathrm{E}-06\end{array}$ & $\begin{array}{c}9.7 \mathrm{E}-07 \\
5.9 \mathrm{E}-07-1.9 \mathrm{E}-06\end{array}$ & $\begin{array}{r}1.1 \\
7.2 \mathrm{E}-07 \\
\end{array}$ \\
\hline Passive Smokers & $33 \%$ & $35 \%$ & $11 \%$ & $46 \%$ & 0 \\
\hline
\end{tabular}

Table 2. Arsenic levels in playground dust $(<20 \mu \mathrm{m})$ and urine, serum MMP-9 levels

\begin{tabular}{cccc}
\hline Arsenic & $\begin{array}{c}\text { Playground } \\
\mathbf{d u s t} \\
(\mathbf{m g} / \mathbf{k g})\end{array}$ & Urine $(\boldsymbol{\mu g} / \mathbf{L})$ & $\begin{array}{c}\text { MMP-9 } \\
(\mathbf{n g} / \mathbf{m L})\end{array}$ \\
\hline $\mathrm{N}$ & 20 & 127 & 127 \\
\hline Mean & 16.9 & 34.9 & 438 \\
\hline Min & 10.5 & 2.39 & 12.1 \\
\hline Max & 23.1 & 200.6 & 1144.4 \\
\hline
\end{tabular}




\begin{tabular}{cccc}
\hline SD & 4.6 & 17.1 & 221 \\
\hline $\begin{array}{c}\text { Soil Mexican } \\
\text { Arsenic Regulation }\end{array}$ & 22.0 & & \\
\hline $\begin{array}{c}\text { Sonora soil Arsenic } \\
\text { background }\end{array}$ & 10.5 & & \\
\hline
\end{tabular}

Table 3. Associations between Arsenic in different media and serum MMP-9 levels in children

\begin{tabular}{|c|c|c|c|c|}
\hline & \multicolumn{2}{|c|}{ Adjusted } & \multicolumn{2}{c|}{ Crude } \\
\hline & Beta $(95 \% \mathrm{CI})$ & $\begin{array}{c}\mathrm{P} \\
\text { value }\end{array}$ & Beta $(95 \% \mathrm{CI})$ & $\begin{array}{c}\mathrm{P} \\
\text { value }\end{array}$ \\
\hline Arsenic in Dust & $20.95(13.11,28.79)$ & $<0.01$ & $19.81(12.12,27.50)$ & $<0.01$ \\
\hline Log Arsenic in Urine & $15.31(-10.69,41.30)$ & 0.25 & $6.05(-18.92,31.01)$ & 0.64 \\
\hline $\begin{array}{c}\text { Log Arsenic Ingestion } \\
\text { Dose }\end{array}$ & $296.32(174.09,418.55)$ & $<0.01$ & $84.63(-45.12,214.38)$ & 0.20 \\
\hline & & & & \\
\hline
\end{tabular}


Covariates in adjusted models include age, sex, BMI, residential time in area, passive smoking, and a random effect for school. Urinary arsenic and arsenic ingestion models include a random effect for school in the crude models. Arsenic in dust models did not include a random effect for school because dust values were the same for all children within each school.

Table 4. Comparison of serum MMP-9 levels relate to arsenic environmental exposed in the present study with values obtained elsewhere.

\begin{tabular}{lllll}
\hline Subject of study & \multirow{2}{*}{} & \multicolumn{2}{c}{ MMP-9 (ng/mL) } & References \\
\cline { 3 - 4 } & & Serum, mean (range) & Sputum (range) & \\
\hline $\begin{array}{l}\text { Mexican children/Hermosillo } \\
\text { (4-12 years) }\end{array}$ & 127 & $438(12.1-1144.4)$ & - & This Study \\
\hline
\end{tabular}




\begin{tabular}{|c|c|c|c|c|}
\hline $\begin{array}{l}\text { USA-Arizona } \\
\text { Non-Hispanic Adults } \\
\text { (19-87 years) } \\
\text { Hispanic adults } \\
\text { (55 years) }\end{array}$ & 214 & $\begin{array}{l}324(41.1-1503) \\
250(41.1-923)\end{array}$ & - & Kurzius-Spe \\
\hline $\begin{array}{l}\text { Mexican children/Coahuila } \\
\text { (6-12 years) }\end{array}$ & 275 & - & $177-334$ & Olivas-Cald \\
\hline $\begin{array}{l}\text { USA-Arizona adults } \\
\text { (19-88 years) } \\
\text { Sonora adults } \\
\text { (43years) }\end{array}$ & $\begin{array}{l}377 \\
162\end{array}$ & $\begin{array}{l}295(274.4-318.5) \\
264.2(235.4-296.5)\end{array}$ & - & Burgess et a \\
\hline $\begin{array}{l}\text { Arizona adults } \\
\text { (30-92 years) }\end{array}$ & 56 & - & 700 & Josyula et al \\
\hline
\end{tabular}




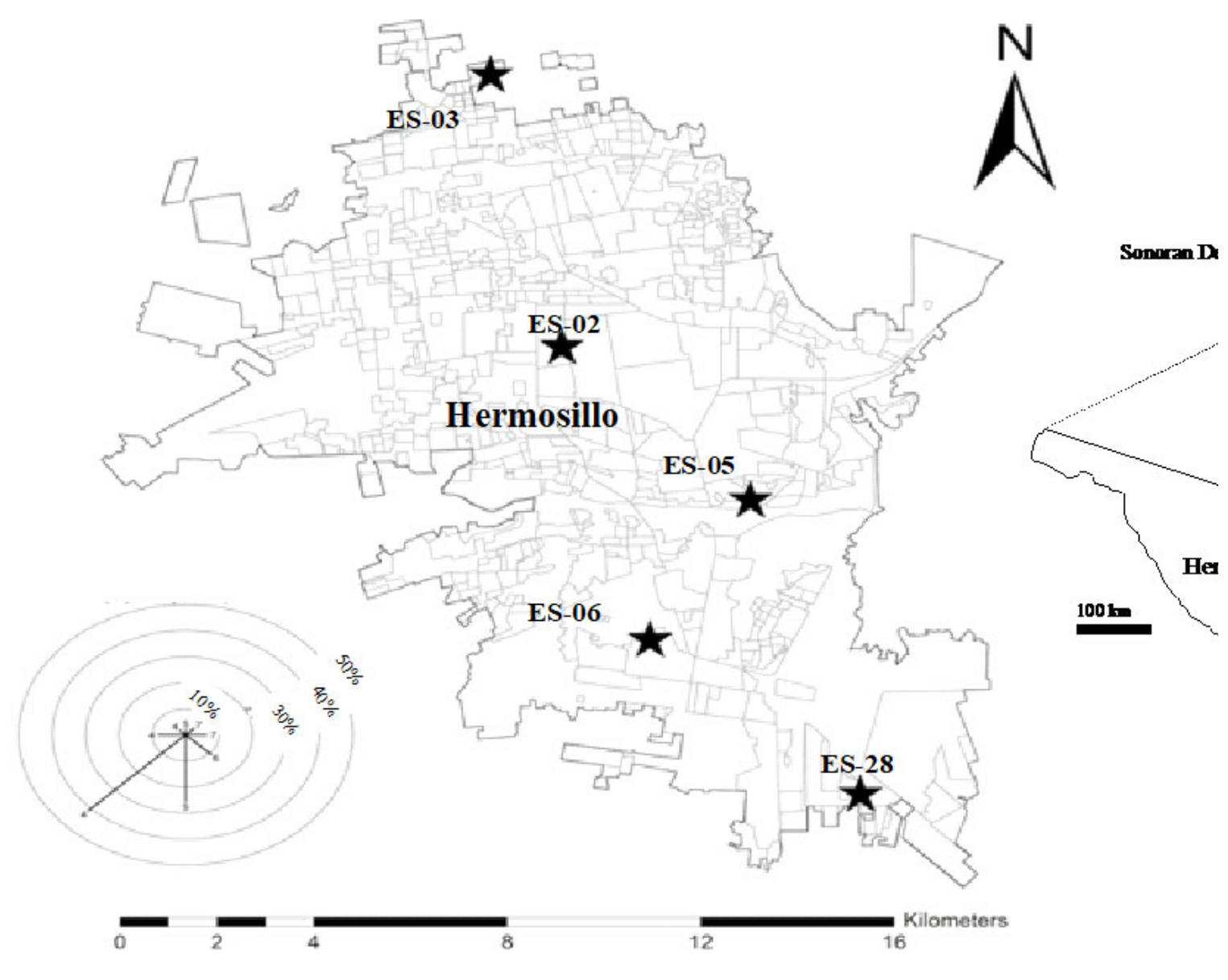

Fig 1 Location of the elementary schoils, in Hermosilla, Sonora, Mexion 


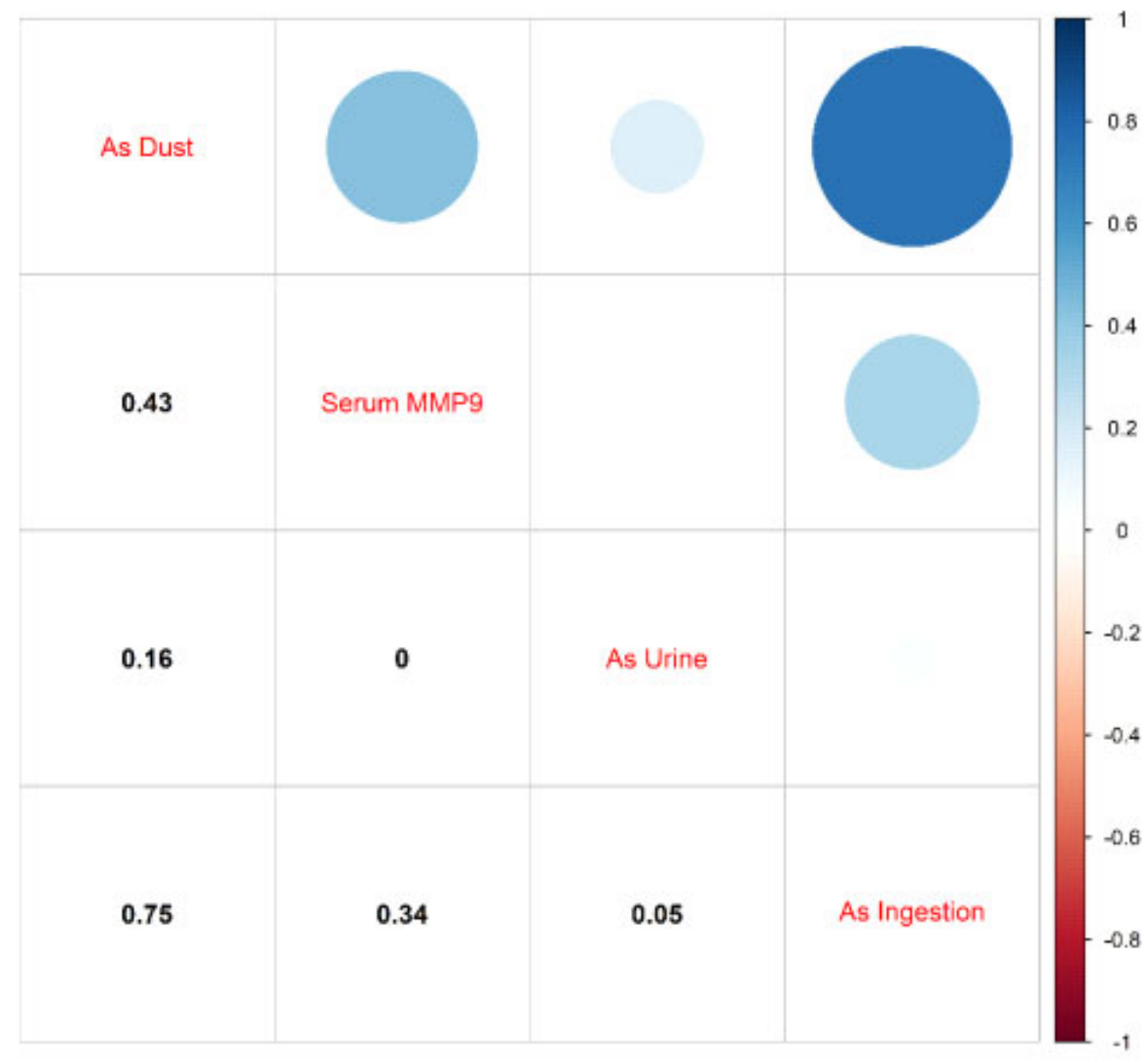

Fig 3_Spearman Cartation Coefficien's between serum MMP-9 levels and Assenicin dust, As in wine and As ingestion. 


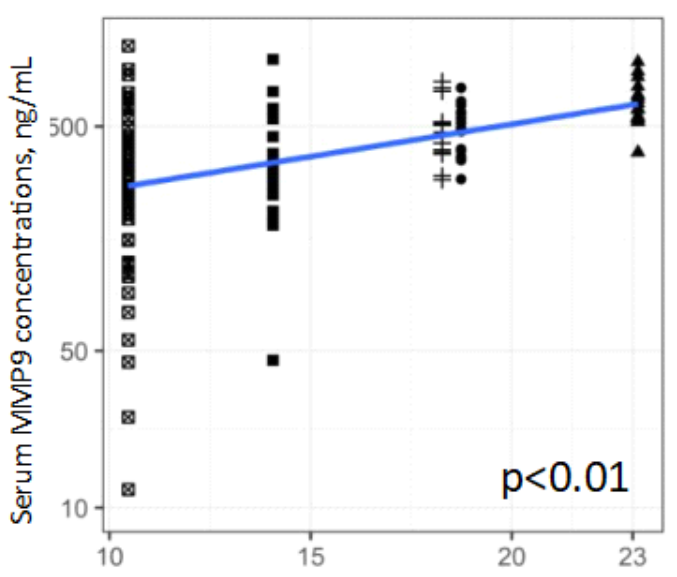

Arsenic Concentrations in playground dust, $\mathrm{mg} / \mathrm{kg}$

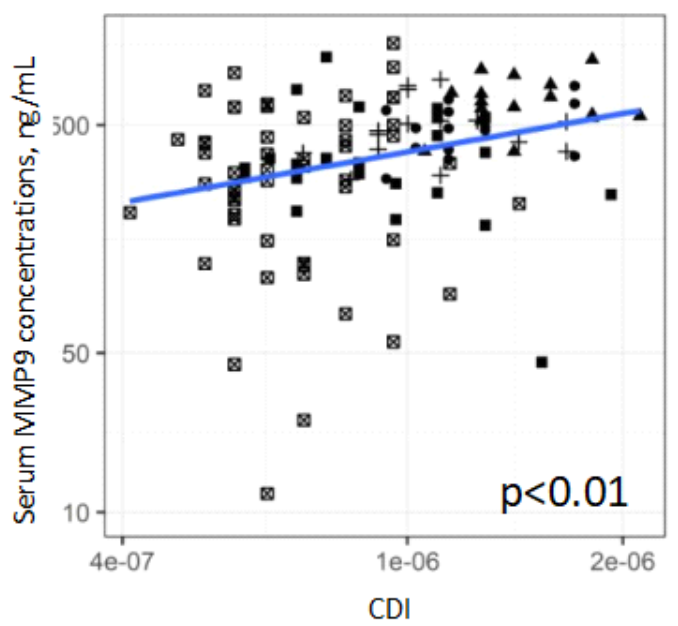

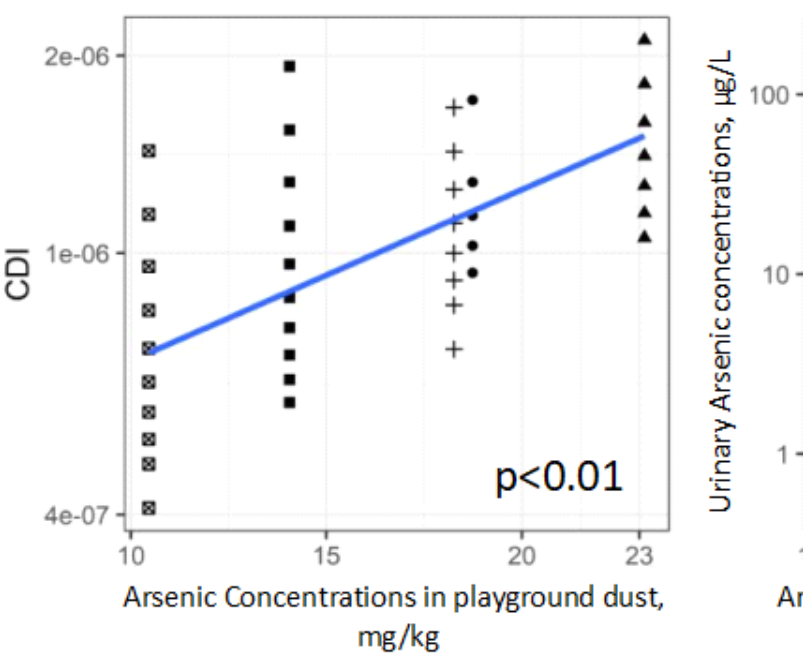

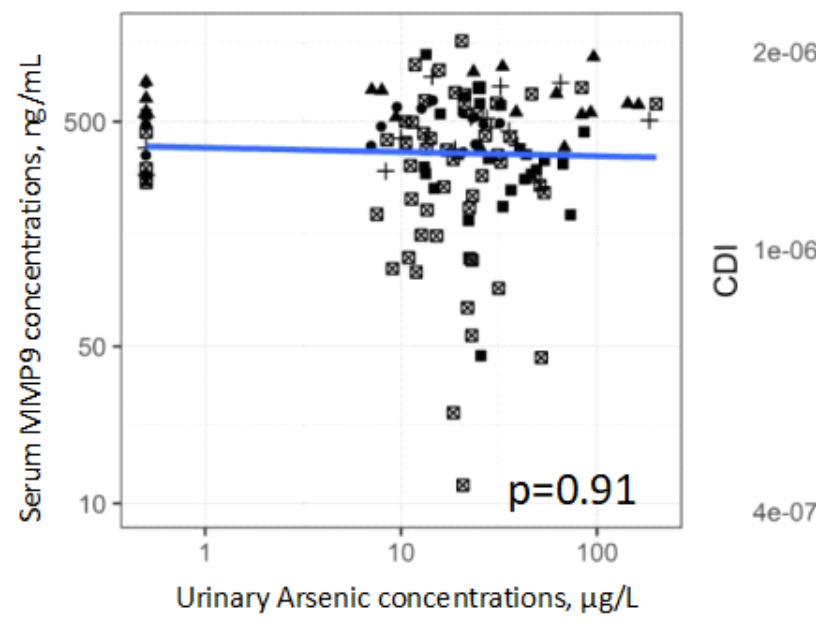

